\title{
A Study on the C-E Translation of Expressions with Chinese Characteristics in 2017 National Government Work Report from the Perspective of Functional Equivalence
}

\author{
Tenglong Xu \\ College of Foreign Languages, University of Shanghai for Science and Technology, Shanghai, China \\ Yan Hua \\ College of Foreign Languages, University of Shanghai for Science and Technology, Shanghai, China
}

\begin{abstract}
Nowadays China plays an increasingly important role in international arena and draws great attention from all over the world. Government Work Report (GWR) reflects the latest and most authoritative work of the present situation in China, which not only summarizes the past work experience, but also puts forward the future work plan. The C-E translation of 2017 GWR is a good reference for people who are interested in $\mathrm{C}$-E translation of political texts and provides a glimpse of China's national conditions for foreign countries. Considering the linguistic and cultural differences between Chinese and English, the author studies the expressions with Chinese characteristics in the 2017 Government Work Report (2017GWR) from perspective of functional equivalence.
\end{abstract}

Index Terms - government work report, functional equivalence, expressions with Chinese characteristics, C-E translation

\section{INTRODUCTION}

The author studies Chinese-English translation of expressions with Chinese characteristics of 2017 GWR based on Nida's functional equivalence. The study consists of three parts. The first part is a brief overview of the definition, classification and features of expressions with Chinese characteristics in 2017GWR. The second part mainly introduces functional equivalence and its contribution to the development of China's translation cause. The third part focuses on the application of functional equivalence theory to the translation of expressions with Chinese characteristics in 2017 GWR.

\section{EXPRESSIONS WITH CHINESE CHARACTERISTICS IN GWR}

Compared to other types of translation, the translation of political text is more stringent. The translation of political text has the very relevance to the image of the nation and government, so it must be taken seriously. If the translation is not accurate or even full of mistakes, it will mislead foreign readers and have negative impacts on their understanding about Chinese national situations and policies. As GWR is one of the most official documents for other countries to understand China's national conditions, the translators should pay attention to the differences of Chinese and western readers' needs, and reproduce the meaning of source text faithfully.

\section{A. Definition of Expressions with Chinese Characteristics}

Over 30 years' reform and opening up, great changes have taken place in China. Correspondingly, a large number of typical expressions with Chinese Characteristics are emerging. Expressions with Chinese characteristics refer to unique expressions which carry typical Chinese ways of thinking and used to describe Chinese typical phenomena.

\section{B. Classification of Expressions with Chinese Characteristics in GWR}

In Accordance with those different forms of expressions with Chinese characteristics, the translation of expressions with Chinese characteristics are mainly classified into four types: the shortened-form phrases, neologisms, culture-loaded expressions and the three-character and four-character expressions, which will be analyzed with specific examples in the third part.

\section{Features of Expressions with Chinese Characteristics in GWR}

New thoughts, new technologies and new phenomena are emerging constantly in China, and expressions with Chinese Characteristics are springing up. These special expressions have two main features: epochal character and rich 
connotations.

1. Epochal character

Expressions with Chinese characteristics can reflect different period of development in many aspects such as politics, economy and culture. Examples are as follow: “人民公社”(the People’s Communes) in 1950s and 1960s; “一国两 制”(One country, two system)in 1980s; “一带一路” (The Belt and Road) in 2015. These expressions gain certain popularity at that time and reflect the change of times.

2. Rich connotations

Chinese people are good at summarizing by using numeral words to abbreviate long expressions with extensive connotations, such as “三农”问题(issues concerning agriculture, rural areas and farmers); 推进“五位一体”总体布局 (Promote balanced economic, political, cultural, social, and ecological progress); 纠正“四风”(address formalism, bureaucratism, hedonism, and extravagance).

\section{INTRODUCTION TO FUNCTIONAL EQUIVALENCE}

Functional equivalence was originally put forward by Eugene A. Nida, a world-famous American translation theorist as well as linguist. Supposed to be one of the most influential translation theorists, Nida inaugurated a new era of the study of modern translation as an academic realm. Nida has also made celebrated contributions to the translation theory and modern linguistics. His translation theory has exerted a tremendous influence on translation research in both China and western countries. Functional equivalence is Nida's greatest contribution to translation theory.

\section{A. Definition and Development of Functional Equivalence}

Functional equivalence theory was first purposed in 1964. Nida defined translation as "Translating consists in reproducing in the receptor language the closet natural equivalent of the source language message, first in terms of meaning and secondly in terms of style" (Nida, 2004). In Nida's article Principles of Translation as Exemplified by Bible Translating (1959), the functional equivalence is called the dynamic equivalence at first. In the book From One Language to Another Language (1986), Nida gradually used "functional equivalence" to take the place of "dynamic equivalence". In fact, the two items have the same implications. Nida thinks that translation should reproduce the source language messages with the closet natural equivalent target languages. Later in his book Language and Culture: Contexts in Translating, Nida distinguished functional equivalence theory into two levels: the minimal equivalence and the maximal equivalence. The former is an ideal condition that translators will pursue all their life. The latter refers to an adequate equivalence that target readers can understand and appreciate what the original readers must learn from the source text. It is the lowest level of the functional equivalence, and translation lower to this level cannot be accepted.

\section{B. Contribution of Functional Equivalence to Chinese Translation Studies}

In early 1980s, Nida's translation theory has spread and gain popularity in China, which plays an important role in learning about the western translation theories for many translators in China and has a profound effect on the China's translation theory research. Despite the doubts on his theory, it is certain that Nida's translation theory gives significant inspiration to translation researchers. Functional equivalence was put forward in the 1986; the theory was then introduced into China. He provided an explanation for the fierce debate between free translation and literal translation among translators existing for a long period. Literal translation pays more attention to "faithfulness" where form should correspond to the original. However, it is easy to neglect the spirit of the source language. On the contrary, free translation emphasizes "elegance" and the receptor language, while often neglects "equivalence" in form. Nida's functional equivalence is devoted to achieving equivalence both in form and content, and it successfully solved the contradiction which hasn't been figured out both by literal and free translation.

\section{Translation of EXPRESSIONS With Chinese Characteristics IN 2017 GWR}

Since any mistakes in the English version can mislead foreign readers, language in national GWR must be accurate. As nowadays China is advancing the Belt and Road Initiative, it is more important to ensure high quality when translating national GWR and other political texts.

\section{A. Difficulties and Guidelines in Translating Expressions with Chinese Characteristics in 2017 GWR}

Many problems may occur during translation, and translating should be guided by translation principles. In this part several difficulties and guidelines in translating GWR will be introduced.

1. Difficulties

The obvious problem in translating GWR is "Chinglish", including: mechanical translation, inappropriate word collocation and improper translation. "Chinglish" refers to the spoken or written English language that is affected by the Chinese language. It is a common phenomenon encountered by those English learners whose first language is Chinese.

Firstly, mechanical translation means that translators mechanically equal certain Chinese expressions to certain English expressions. Take the word “建设” as an example, the Chinese meaning is generally quite general and vague, while the English meaning is often specific and well-defined. Therefore, “加强社会主义精神文明建设” is translated 
into “foster stronger observance of socialist cultural and ethical standards”; “建设富强民主文明和谐的社会主义现代 化国家” is translated into "build China into a modern socialist country that is prosperous, strong, democratic, culturally advanced, and harmonious”; “一一带一路”建设” is translated into “the Belt and Road Initiative”; “推进健康中国建设” is translated into"make continued progress in building a Healthy China”. Secondly, inappropriate word collocation often occurs when translator don't have a good command of language. Thirdly, improper translation refers to redundant expressions and the abuse of commendatory and derogatory words. Unnecessary words make translation not succinct. In addition, sometimes the commendatory words can be used as derogatory terms and vice versa.

2. Guidelines

According to Nida's functional equivalence, a translation has to meet the four basic requirements: conveying the spirit and manner of source language; making sense; having a natural and easy form of expression and producing a similar response, which is also true in the translation of political texts. the author believed that the guidelines in translating GWR are accuracy, faithfulness and expressiveness.

GWR is the authoritative political document concerning national major policies and situation. Inaccurate translation will mislead foreign readers and have negative impacts on the image of Chinese government. Translators should fully understand the importance of accuracy and faithfulness in political documents from the perspective of cross-culture exchanges. Meanwhile, a good translation is very natural and has no obvious trace of translating. In order to achieve the expressiveness, translators should be proficient in the source language and the target language.

\section{B. Application of Functional Equivalence to Translation of Expressions with Chinese Characteristics in 2017 GWR}

From the above discussion, the thesis gives the definition of the expressions with Chinese characteristics, which refers to the unique expressions which carry typical Chinese ways of thinking and used to express Chinese typical phenomena. Forms of expressions with Chinese characteristics include shortened-form phrases with number, neologisms, culture-loaded expressions and Chinese three-character and four-character structure.

1. Translation of shortened-form phrases with number

Many shortened forms with numbers are used to express some China's unique national policies and situation for the purpose of concise expression and balanced structure. By observing many shortened forms adopted from 2017 GWR, it is not difficult to find the application of functional equivalence. Examples are as follows:

Example 1: “三农”;

translation: Agriculture, rural areas and farmers (From 2017 GWR)

Example 2: “三公” 经费;

translation: official overseas visits, official vehicles, or official hospitality (From 2017 GWR)

Example 3: “约法三章”;

translation: The State Council's three-point decision on curbing government spending (From 2017 GWR)

Example 4: “三去一降一补”;

translation: five priority tasks -- cutting overcapacity, reducing excess inventory, deleveraging, lowering costs, and strengthening areas of weakness (From 2017 GWR)

Example 5: “两学一做”;

translation: gain a good understanding of the Party Constitution, Party regulations, and General Secretary Xi Jinping's major policy addresses and to meet Party standards (From 2017 GWR)

Example 6: 纠正“四风”;

translation: address formalism, bureaucratism, hedonism, and extravagance (From 2017 GWR)

Example 7: “四个意识”;

translation: willingly maintain political integrity, think in big-picture terms, uphold the leadership core, and keep in alignment (From 2017 GWR)

Example 8: 国务院“约法三章”;

translation: the State Council's three-point decision on curbing government spending (From 2017 GWR)

Example 9: 统筹推进 “五位一体”总体布局;

translation: Promote balanced economic, political, cultural, social, and ecological progress (From 2017 GWR)

Example 10: “四个全面”战略布局;

translation: the Four-Pronged Comprehensive Strategy (From 2017 GWR)

Example 11: “十三五”规划;

translation: the 13th Five-Year Plan (From 2017 GWR)

Example 12: “双随机、一公开”;

translation: random inspection and public release across the board (From 2017 GWR)

Example 13: 农村土地“三权分置”;

translation: separating rural land ownership rights, contract rights, and management rights (From 2017 GWR)

Example 14: “两免一补”政策; 
translation: waive tuition and miscellaneous fees, supply free textbook (From 2017 GWR)

Example 15: “双创”政策;

translation: encourage people to launch businesses and innovate (From 2017 GWR)

Taking “四个全面” and “四个意识” for example, which have the same language structures in Chinese, but the latter cannot sustain its shortened form in translation. “四个全面” could be translated into "the Four-Pronged Comprehensive Strategy", but “四个意识” have to be translated as “willingly maintain political integrity, think in big-picture terms, uphold the leadership core, and keep in alignment”.(From 2017 GWR). Only in this way could the content of “四个意 识” be explained clearly. From the perspective of functional equivalence, both of two translations, to some degree, realize the faithfulness and the former focus on the form while the latter emphasizes on the content. Due to great distinction between different languages, most shortened-form phrases with number should be demonstrated clearly in translation of 2017 GWR.

2. Translation of neologisms

Neologisms are defined as new words, phrases to describe new or specific policies, times or events, most of which are totally new concepts and have strong Chinese flavors. Neologisms are especially worth analyzing as a kind of specific words in GWR. Due to the conflict between languages, cultures and values, it is quite difficult for translators to find the accurate equivalence in English. Some neologisms adopted from 2017 GWR and their translations will be gathered and discussed. Examples are as follows:

Example 1: “一带一路”建设;

translation: the Belt and Road Initiative (From 2017 GWR)

Example 2: “四个全面”战略布局;

translation: the Four-Pronged Comprehensive Strategy (From 2017 GWR)

Example 3: 经济发展新常态;

translation: the new normal in China's economic development (From 2017 GWR)

Example 4: 供给侧结构性改革;

translation: supply-side structural reform (From 2017 GWR)

Example 5: 大众创业、万众创新;

translation: people are busy launching businesses or making innovations (From 2017 GWR)

Example 6: 营改增;

translation: replacement of business tax with value added tax (From 2017 GWR)

Example 7: “深港通”;

translation: The Shenzhen-Hong Kong Stock Connect (From 2017 GWR)

Example 8: “互联网+”;

translation: The Internet Plus (From 2017 GWR)

Example 9: “两学一做”;

translation: gain a good understanding of the Party Constitution, Party regulations, and General Secretary Xi Jinping's major policy addresses and to meet Party standards (From 2017 GWR)

Example 10:工匠精神;

translation: workmanship (From 2017 GWR)

Example 11: 中国制造 2025;

translation: Made in China 2025 initiative (From 2017 GWR)

Functional equivalence emphasizes the functional equivalence of information instead of the direct formal equivalence in translation, which allows translators to translate flexibly as much as possible in a relative range to bridge the differences of two languages. When translating neologisms, translators should analyze and understand the content of original text comprehensively. And the translators also have to know the official translation given by China's official institutions.

3. Translation of culture-loaded expressions

Culture-loaded expressions are difficult to be understood by the foreigners because of its own cultural background. Therefore, the translator has the responsibility to ensure them readable. There are some culture-loaded expressions adopted from 2017 GWR. Examples are as follows:

Example 1: 在稳的前提下要勇于进取, 深入推进改革, 加快结构调整, 敢于啃“硬骨头”, 努力在关键领域取 得新进展。

We should, while maintaining stable performance, endeavor to make progress, deepen reforms, accelerate structural adjustments, be prepared to take on some really tough problems, and push to make progress in key areas. (From 2017 GWR)

Example 1: 我们要咬定青山不放松, 持之以恒为群众办实事、解难事, 促进社会公平正义, 把发展硬道理更 多体现在增进人民福祉上。 
Translation: We must make dedicated efforts to deliver services to the people, resolve the difficulties they face, promote social equity and justice, and demonstrate that development does better people's lives. (From 2017 GWR)

Example 2: 使城市既有“面子”、更有“里子”。

Translation: All these efforts will make our cities more attractive and function better. (From 2017 GWR)

Example 3: 坚决打好蓝天保卫战。

Translation: We will make our skies blue again. (From 2017 GWR)

Example 4: 各级政府要坚持过紧日子, 中央部门要带头, 一律按不低于 5\%的幅度压减一般性支出。

Translation: Governments at all levels should tighten their belts, and central government departments should take the lead by cutting no less than 5 percent of their general expenditures. (From 2017 GWR)

Example 5: 这是政府自身的一场深刻革命, 要继续以壮士断腕的勇气, 坚决披荆斩棘向前推进。

Translation: This is a profound reform of government itself, which we need to continue to pursue with the courage to make painful self-adjustments and overcome all odds. (From 2017 GWR)

Example 6: 政府要带头讲诚信, 决不能随意改变约定, 决不能“新官不理旧账”。

Translation: Government must take the lead in acting in good faith and must never arbitrarily change agreements, and new officials must not disavow obligations undertaken by their predecessors. (From 2017 GWR)

The underline parts in 2017 GWR are some culture-loaded expressions which are deeply rooted in Chinese culture. These texts cannot be just translated just as their literal meanings according to Nida's theory which was devoted into achieving equivalence both in form and content.

In example 1, “啃了不少硬骨头” was translated as “we tackled many tough issue” instead of “eat some hard bones”; In example 4 “打好蓝天保卫战” does not mean to have a war. It was better to be translated as “make our skies blue again”. The culture-loaded expressions are quite difficult to find their counterparts in western culture, like “面子”, “里 子” in example 3. Therefore, while translating some culture-loaded expressions, the original form of metaphor disappears and only the connotation of metaphor is kept.

4. Translation of Chinese three-character and four-character structure

The Chinese three-character and four-character expressions have many advantages in political texts, such as concise structure, extensive meaning, passionate rhythm and aesthetic feeling. Chinese people are good at making elegant sentence in composition, instead of expanding the organization of sentence. The Chinese like to use the three-character and four-character short sentences to create precise, concise and compact texture. Examples adopted from 2017 GWR are as follows:

Example 1: 我们一定要直面挑战, 敢于担当, 全力以赴做好政府工作，不辱历史使命，不负人民重托。

Translation: We must confront these challenges head-on, be ready to bear the weight of responsibility, and do our all to deliver. We must fulfill our historic mission and live up to the great trust placed in us by the Chinese people. (From 2017 GWR)

Example 2: 全面做好稳增长、促改革、调结构、惠民生、防风险各项工作。

Translation: Maintain stable growth, promote reform, make structural adjustments, improve living standards, and guard against risks. (From 2017 GWR)

Example 3: 必须把改善供给侧结构作为主攻方向, 通过简政减税、放宽准入、鼓励创新。

Translation: We must give priority to improving supply-side structure. We should streamline administration, reduce taxes, further expand market access, and encourage innovation. (From 2017 GWR)

Example 4: 必须科学施策、标本兼治、铁腕治理, 努力向人民群众交出合格答卷。

Translation: We must adopt well-designed policies, tackle both symptoms and root causes, and take tough steps to make the grade in responding to the people. (From 2017 GWR)

Example 5: 这再次表明, 中国人民有勇气、有智慧、有能力战胜任何艰难险阻, 中国经济有潜力、有韧性、 有优势, 中国的发展前景一定会更好。

Translation: Once again, this shows that we the Chinese people have the courage, ingenuity, and ability to overcome any difficulty or hardship. It also shows that the Chinese economy possesses potential, resilience, and strengths, so we can be sure there is even better development ahead for China. (From 2017 GWR)

If we translate the Chinese character phrases into English without any changes in structure, mistakes will happen during the process. According to functional equivalence, the three-character and four-character structure can be broken while the meaning is maintained in translation like examples mentioned above. The form of three-character and four-character phrases is flexible, and there is no need to keep the same structure in translating. If adequate equivalence can be achieved in translated text, the free translation could be an effective way for us to express the exact meaning of three-character and four-character phrases.

\section{CONCLUSION}

The study focuses on Chinese-English translation of expressions with Chinese characteristics of 2017 GWR based on Nida's functional equivalence. It has provided many detailed examples of the translation of expressions with Chinese characteristics in 2017 GWR and also pointed out some difficulties and principles in translation. This study introduces 
four forms of expressions with Chinese characteristics, shorten-form phrases, neologisms, culture-loaded expressions and three-character and four-character phrases.

A thorough understanding of original text is the necessary for the application of functional equivalence and accuracy is the primary consideration in the translation of political text. The author holds the opinion that the translator should reconstruct the form of the original text if a literal translating can't achieve functional equivalence.

By analyzing detailed examples of expressions with Chinese characteristics in the English version of 2017 GWR, it further emphasizes functional equivalence is an important translation strategy for the translation of expressions with Chinese characteristics in political text.

\section{REFERENCES}

[1] Baker, M. (2000). In Other Words: A Course book on Translation. Beijing: Foreign Language Teaching and Research Press. 61.

[2] China Academy of Translation. (2017). China's 2017 Government Work Report (2017 GWR) delivered by Premier Keqiang Li (Chinese and English version). http://www.china.org.cn/chinese/cat1/2017-03/17/content_40498347.htm. (accessed 20/9/2017).

[3] Dan Jiang. (2013). A Study on the Translation of Vocabulary with Chinese Characteristics in the Report on the work of the Government. master dissertation, Xiamen University.

[4] Jianzhong Guo. (2005). Culture and Translation. Beijing: China Translation Corporation, 78-82.

[5] Newmark, P. (2001). A Textbook to Translation. Shanghai: Shanghai Foreign Language Education Press, 53-59.

[6] Nida, E. A. (2004). Language and Culture: Contexts in Translating. Shanghai: Shanghai Foreign Language Education Press, 27-28.

[7] Nida, E. A. \& Taber, C.R. (2004). The Theory and Practice of Translation. Shanghai: Shanghai Foreign Language Education Press, 12-33.

[8] Xiaoli Luan. (2013). Study on Chinese-English Translation of Lexical Items with Chinese Characteristics in 2010-2012 Government Work Report---Based on Nida's Functional Equivalence Theory. master dissertation, Ocean University of China.

Tenglong Xu was born in Anhui, China in 1994. He is a postgraduate student majoring in translation and interpreting in College of Foreign Languages, University of Shanghai for Science and Technology (USST).

Yan Hua was born in China on March 18, 1961. She received her Master of Arts in University of Shanghai for Science and Technology (USST) on June 30, 1996.

She is currently an associate professor in College of Foreign Languages, University of Shanghai for Science and Technology. Her research interests include Australian literature, teaching methodology and translation.

Professor Hua is the Deputy Director of Centre for Studies of Australian Affairs \& Western Culture of College of Foreign Languages, USST. 